\title{
POLA KONVERSI LAHAN TANAMAN BUDIDAYA DI PROVINSI JAMBI
}

\author{
Eva Maya Sari \\ Program Studi Agribisnis Universitas Pendidikan Muhammadiyah Sorong \\ eva.mayasari27@gmail.com
}

\begin{abstract}
ABSTRAK
Penelitian ini bertujuan untuk menganalisis dampak perubahan faktor sosial dan ekonomi terhadap luas lahan beberapa budidaya tanaman di Provinsi Jambi dan untuk mengidentifikasi pola konversi lahan antara berbagai tanaman yang dibudidayakan di provinsi Jambi. Untuk menjawab tujuan dalam penelitian digunakan model ekonometrik Seemingly Unrelated Regression (SUR) model terdiri dari 9 persamaan dengan 8 persamaan perilaku dan satu persamaan identitas dan termasuk 8 variabel endogen dan 16 variabel eksogen. Hasil penelitian menunjukkan bahwa perubahan yang terjadi pada areal tanaman pangan lebih dipengaruhi oleh faktor ekonomi (harga komoditas, pangsa subsektor pangan) dan pertumbuhan serta kepadatan penduduk, dengan kecenderungan menurun setiap tahun. Perubahan area perkebunan lebih dipengaruhi oleh struktur ekonomi (harga komoditas, pangsa sektor pertanian, pangsa subsektor perkebunan, PDB per kapita, pertumbuhan ekonomi) dan faktor sosial (tenaga kerja, kepadatan dan pertumbuhan populasi) dengan kecenderungan meningkat setiap tahun kecuali kelapa. Pola konversi lahan tanaman budidaya di Provinsi Jambi, yaitu perubahan pola penggunaan lahan budidaya tanaman pangan menjadi tanaman komersial, perluasan perkebunan kelapa sawit dan karet. Perluasan perkebunan kelapa sawit dan karet menyebabkan menipisnya lahan yang tersedia untuk tanaman pangan, terutama padi (padi dan sawah) yang mengganggu ketahanan pangan.

Kata kunci: Konversi, lahan, faktor sosial dan ekonomi, budidaya tanaman.
\end{abstract}

\begin{abstract}
This study aimed to analyze the impact of changes in social and economic factors against the land area of some crops cultivation in Jambi Province and to identify the patterns of land conversion between various crops cultivated in the province of Jambi. To answer the purpose in the study used an econometric model Seemingly Unrelated Regression (SUR) model consisted of 9 equations with 8 equations behavior and one equation identity and includeed 8 endogenous variables and 16 exogenous variables. The results showed that the changes that occurred in the area of food crops is more influenced by economic factors (commodity prices, share food subsector) and growth as well as population density, with a tendency is decreased each year. Changes in the plantation area was more influenced by the structure of the economy (commodity prices, share the agricultural sector, share plantation subsector, GDP per capita, economic growth) and social factors (labor, density and population growth) with a tendency to increase every year except coconut. The pattern of land conversion of cultivated plants in Jambi Province, namely changes in land use patterns of cultivation of food crops into cash crops, the expansion of oil palm and rubber plantations. The expansion of oil palm plantations and rubber led to the depletion of land available for food crops, especially rice (paddy rice and paddy fields) that interfere with food security.
\end{abstract}

Keywords: Conversion, land, social and economic factors, crop cultivation.

\section{PENDAHULUAN}

Lahan memiliki arti penting, yakni sebagai tempat manusia beraktivitas untuk mempertahankan eksistensi. Aktivitas yang pertama kali dilakukan adalah pemanfaatan lahan untuk bercocok tanam guna menghasilkan bahan pangan pokok bagi kebutuhan manusia [1]

Di Provinsi Jambi lahan yang digunakan untuk budidaya tanaman memiliki proporsi paling besar yaitu $54,71 \%$, sisanya $41,52 \%$ adalah hutan dan $3,77 \%$ digunakan untuk pemukiman dll [2]. Selama periode 15 tahun terakhir terjadi peningkatan luas lahan perkebunan, terutama perkebunan komoditi unggulan di Provinsi Jambi seperti perkebunan kelapa sawit, karet, dan pinang. Namun hal berbeda justru tampak pada luasan tanaman pangan yang semakin berkurang. Penyusutan lahan pertanian tanaman pangan di Provinsi Jambi disebabkan oleh adanya alih fungsi lahan (konversi lahan). Apabila penurunan luas lahan tersebut terus berlangsung bahkan tidak terkendali, maka pada saatnya nanti Provinsi Jambi akan mengalami kekurangan pangan [3].

Konversi lahan yang dipicu oleh perubahan faktor sosial ekonomi di masyarakat tidak bisa dihindari karena merupakan konsekuensi logis pembangunan. Apabila konversi lahan pertanian terus menerus berlangsung akan menimbulkan berbagai masalah pangan, ketenagakerjaan, lingkungan, dan lain-lain sehingga perlu adanya perencanaan penggunaan lahan yang baik dalam rangka pengendalian konversi lahan. Untuk itu perlu diketahui lebih dahulu mengenai pola konversi lahan dan dampak dari perubahan faktor sosial ekonomi terhadap konversi lahan tanaman budidaya di Provinsi Jambi. 
Berdasarkan uraian diatas maka tujuan dari penelitian ini adalah:

1. Menganalisis dampak perubahan faktor sosial ekonomi terhadap luas lahan beberapa komoditas tanaman budidaya di Provinsi Jambi.

2. Mengidentifikasi pola konversi lahan antar berbagai komoditas tanaman pangan ke perkebunan di Provinsi Jambi.

\section{METODE PENELITIAN}

Penelitian ini dilaksanakan di Provinsi Jambi. Dalam penelitian ini, dilakukan pemilihan komoditas tanaman budidadaya yang dibatasi pada komoditas penting dan unggulan dengan proses produksi sangat tergantung pada lahan dengan proporsi luas penggunaan lahan dominan dan tersebar secara merata di Provinsi Jambi seperti tanaman perkebunan (karet, kelapa sawit, kelapa dalam, kopi, pinang) tanaman pangan (padi sawah, padi ladang, jagung).

Jenis data yang digunakan dalam penelitian ini adalah data sekunder. Data sekunder yang digunakan adalah data yang dicatat secara sistematis yang berbentuk data runtun waktu (time series) data. Data yang diperoleh diolah menggunakan program komputer Statistical Analysis System (SAS). Untuk menjawab tujuan pertama penelitian, model ekonometrika yang digunakan adalah model Seemingly Unrelated Regression (SUR). Perubahan penggunaan lahan berlangsung dinamis yang berarti mengandung dimensi waktu sehingga tahun sebagai variabel trend dapat diintroduksi sebagai eksogen. Persamaan dalam model terdiri dari 9 persamaan yaitu 8 persamaan perilaku dan 1 persamaan identitas dan mencakup 8 variabel endogen dan 14 variabel eksogen dengan model persamaannya sebagai berikut :

Porsi Luas Areal Padi Sawah (PLAPS)

PLAPS $=\mathrm{a}_{1.0}+\mathrm{a}_{1.1}$ lag PBRR $+\mathrm{a}_{1.2} \mathrm{SSPG}+\mathrm{a}_{1.3} \mathrm{SSAG}+$ $\mathrm{a}_{1.4}$ GDPK $+\mathrm{a}_{1.5}$ ECGR $+\mathrm{a}_{1.6}$ POPG + $\mathrm{a}_{1.7}$ TPAK $+\mathrm{a}_{1.8}$ DEPR $+\mathrm{a}_{1.9}$ YEAR $\mathrm{e}_{1} \ldots \ldots \ldots \ldots \ldots \ldots . . . . . . .(1)$

Parameter dugaan: $\mathrm{a}_{1.1}, \mathrm{a}_{1.2}, \mathrm{a}_{1.3}, \mathrm{a}_{1.6}, \mathrm{a}_{1.7}>0$ dan $\mathrm{a}_{1.4}, \mathrm{a}_{1.5}$ , $\mathrm{a}_{1.6}, \mathrm{a}_{1.8}, \mathrm{a}_{1.9}<0$

Porsi Luas Areal Padi Ladang (PLAPD)

PLAPD $=\mathrm{a}_{2.0}+\mathrm{a}_{2.1} \mathrm{PBRR}+\mathrm{a}_{2.2} \mathrm{SSPG}+\mathrm{a}_{2.3} \mathrm{SSAG}+$ $\mathrm{a}_{2.4} \mathrm{GDPK}+\mathrm{a}_{2.5}$ ECGR $+\mathrm{a}_{2.6}$ POPG + $\mathrm{a}_{2.7}$ TPAK $+\mathrm{a}_{2.8}$ DEPR $+\mathrm{a}_{2.9}$ YEAR $\mathrm{e}_{2} \ldots \ldots \ldots \ldots \ldots \ldots \ldots(2)$

Parameter dugaan: $a_{2.1}, a_{2.2}, a_{2.3}, a_{2.7}>0$ dan $a_{2.4}, a_{2.5}$, $\mathrm{a}_{2.6}, \mathrm{a}_{2.8}, \mathrm{a}_{2.9}<0$

Porsi Luas Areal Jagung (PLAJG)

PLAJG $=\mathrm{a}_{3.0}+\mathrm{a}_{3.1}$ PJGR $+\mathrm{a}_{3.2} \mathrm{SSPG}+\mathrm{a}_{3.3} \mathrm{SSAG}+$ $\mathrm{a}_{3.4} \mathrm{GDPK}+\mathrm{a}_{3.5} \mathrm{ECGR}+\mathrm{a}_{3.6}$ POPG + $\mathrm{a}_{3.7}$ TPAK $+\mathrm{a}_{3.8}$ DEPR $+\mathrm{a}_{3.9}$ YEAR + $\mathrm{e}_{3} \ldots \ldots \ldots \ldots \ldots \ldots \ldots . . . . . . . . . . .(3)$

Parameter dugaan: $\mathrm{a}_{3.1}, \mathrm{a}_{3.2}, \mathrm{a}_{3.3}, \mathrm{a}_{3.7}, \mathrm{a}_{3.11}>0$ dan $\mathrm{a}_{3.4}, \mathrm{a}_{3.5}, \mathrm{a}_{3.6}, \mathrm{a}_{3.8}, \mathrm{a}_{3.9}<0$
Porsi Luas Areal Karet (PLAKR)

PLAKR $=b_{1.0}+b_{1.1}$ PKRR $+b_{1.2}$ SSKB $+b_{1.3}$ SSAG+ $\mathrm{b}_{1.4} \mathrm{GDPK}+\mathrm{b}_{1.5} \mathrm{ECGR}+\mathrm{b}_{1.6}$ POPG + $\mathrm{b}_{1.7} \mathrm{TPAK}+\mathrm{b}_{1.8}$ DEPR $+\mathrm{b}_{1.9}$ YEAR+ $\mathrm{e}_{4} \ldots \ldots \ldots \ldots \ldots \ldots \ldots \ldots . . . . . . . . . . .(4)$

Parameter dugaan: $b_{1.1}, b_{1.2}, b_{1 . .3}, b_{1 . .4}, b_{1 . .5} b_{1 . .7}, b_{1 . .9}>$ 0 dan, $\mathrm{b}_{1 . .6,}, \mathrm{~b}_{1.8}<0$

Porsi Luas Areal Kelapa Sawit (PLAKS)

PLAKS $=b_{2.0}+b_{1.1}$ PKSR $+b_{2.2}$ SSKB $+b_{2.3}$ SSAG + $\mathrm{b}_{2.4} \mathrm{GDPK}+\mathrm{b}_{2.5} \mathrm{ECGR}+\mathrm{b}_{2.6}$ POPG + $\mathrm{b}_{2.7} \mathrm{TPAK}+\mathrm{b}_{2.8} \mathrm{DEPR}+\mathrm{b}_{2.9}$ YEAR $+\mathrm{e}_{5}$.

Parameter dugaan: $b_{2.1}, b_{2.2}, b_{2.3}, b_{2.4}, b_{2.5}, b_{2.7}, b_{2.9}>0$ dan $b_{2.6}, b_{2.8}<0$

Porsi Luas Areal Kelapa (PLAKL)

PLAKL $=b_{3.0}+b_{3.1}$ PKLR $+b_{3.2}$ SSKB $+b_{3.3}$ SSAG + $\mathrm{b}_{3.4} \mathrm{GDPK}+\mathrm{b}_{3.5} \mathrm{ECGR}+\mathrm{b}_{3.6}$ POPG + $\mathrm{b}_{3.7} \mathrm{TPAK}+\mathrm{b}_{3.8}$ DEPR $+\mathrm{b}_{3.9}$ YEAR $+\mathrm{e}_{6} \ldots$

Parameter dugaan: $b_{3.1}, b_{3.2}, b_{3.3}, b_{3.4}, b_{3.5}, b_{3.7}, b_{3.9}>0$ dan $b_{3.6}, b_{3.8}<0$

Porsi Luas Areal Kopi (PLAKP)

PLAKP $=b_{4.0}+b_{4.1}$ PKPR $+b_{4.2} \mathrm{SSKB}+\mathrm{b}_{4.3} \mathrm{SSAG}+$ $\mathrm{b}_{4.4} \mathrm{GDPK}+\mathrm{b}_{4.5} \mathrm{ECGR}+\mathrm{b}_{4.6} \mathrm{POPG}+$ $\mathrm{b}_{4.7} \mathrm{TPAK}+\mathrm{b}_{4.8} \mathrm{DEPR}+\mathrm{b}_{4.9}$ YEAR $+\mathrm{e}_{7} \ldots \ldots \ldots \ldots \ldots . . . . . . .(7)$

Parameter dugaan: $\mathrm{b}_{4.1}, \mathrm{~b}_{4.2}, \mathrm{~b}_{4.4}, \mathrm{~b}_{4.3}, \mathrm{~b}_{4.5}, \mathrm{~b}_{4.7}, \mathrm{~b}_{4.9}>0$ dan $\mathrm{b}_{4.6}, \mathrm{~b}_{4.8}<0$

Porsi Luas Areal Pinang (PLAPN)

PLAPN $=b_{5.0}+b_{5.1}$ PPNR $+b_{5.2}$ SSKB $+b_{5.3}$ SSAG + $\mathrm{b}_{5.4} \mathrm{GDPK}+\mathrm{b}_{5.5} \mathrm{ECGR}+\mathrm{b}_{5.6}$ POPG + $b_{5.7}$ TPAK $+b_{5 .}$ DEPR $_{8}+b_{5.9}$ YEAR $+\mathrm{e}_{8} \ldots$ (8)

Parameter dugaan: $b_{5.1}, b_{5.2}, b_{5.3}, b_{5.4}, b_{5.5}, b_{5.7}, b_{5.9}>0$ dan $b_{5.6} b_{5.8}<0$

Porsi Luas Areal Komoditas Lainnya

PLAOT = 100- PLAPS - PLAPD - PLAJG - PLAKR PLAKS -PLAKL - PLAKP PLAPN

Dimana:

PLAPS : Porsi Luas Areal Padi Sawah (\%)

PLAPD : Porsi Luas Areal Padi Ladang (\%)

PLAJG : Porsi Luas Areal Jagung (\%)

PLAKR : Porsi Luas Areal Karet (\%)

PLAKS : Porsi Luas Areal Kelapa Sawit (\%)

PLAKL : Porsi Luas Areal Kelapa (\%)

PLAKP : Porsi Luas Areal Kopi (\%)

PLAPN : Porsi Luas Areal Pinang (\%)

PLAOT : Porsi Luas Areal Komoditas Lain (\%)

PBRR : Harga Beras Riel (\%)

PJGR : Harga Jagung Riel (\%)

PKRR : Harga Karet Riel (\%)

PKSR : Harga Kelapa Sawit Riel (\%)

PKLR : Harga Kelapa Riel (\%) 
PKPR : Harga Kopi Riel (\%)

PPNR : Harga Pinang Riel (\%)

SSPG :Proporsi PDRB sub-sektor pangan

SSKB :Proporsi PDRB sub-sektor perkebunan(\%)

ECGR : Laju pertumbuhan ekonomi (\%)

TPAK :Tingkat Partisipasi Angkatan Kerja

DEPR : Dependency Ratio (\%)

POPG : Laju Pertumbuhan Penduduk $(\%)$

YEAR : Tahun

Untuk menjawab tujuan kedua yaitu mengidentifikasi pola konversi lahan antar berbagai komoditas tanaman budidaya di Provinsi Jambi digunakan matrik korelasi silang (Cross Model Correlation) dari hasil estimasi menggunakan SUR (Seemingly Unrelated Regression) [4].

Berdasarkan matrik korelasi silang dapat dilihat pola konversi yaitu perubahan proporsi luas areal komoditas $i$ sebesar satu satuan akan berdampak pada perubahan (peningkatan atau pengurangan) luas areal komoditas yang lain.

\section{HASIL DAN PEMBAHASAN}

3.1. Dampak Faktor Sosial Ekonomi Terhadap Luas Lahan Tanaman Budidaya

Berdasarkan hasil estimasi dari model persamaan ekonometrika yang digunakan dalam penelitian ini menunjukkan bahwa tingkat kevalidan model yang digunakan dalam penelitian ini sangat baik. Hal ini terbukti dari indikator nilai koefisien determinasi $\left(\mathrm{R}^{2}\right)$ yang menunjukkan angka 0,9979. Nilai R-square $=0,9979$ dapat diinterpretasikan bahwa sekitar 99,79 persen variasi luas lahan tanaman budidaya dapat dijelaskan oleh variabel sosial dan ekonomi dalam penelitian ini dan sisanya atau sekitar 0,21 persen lagi dijelaskan oleh variabel lainnya yang tidak termasuk di dalam model. Selain itu,untuk meyakinkan bahwa hasil estimasi terbebas dari masalah autocorrelation yang muncul karena adanya korelasi antara anggota observasi satu dengan observasi lain yang berurutan sepanjang waktu, maka dalam penelitian ini dilakukan uji autokorelasi menggunakan metode Durbin-Watson. Dengan menggunakan Tabel Durbin Watson pada $\alpha=5 \%, \mathrm{n}$ $=23$ observasi, dan $\mathrm{k}=$ variabel bebas, hasil pengujian menunjukkan bahwa nilai DW dari seluruh hasil estimasi berada diantara dU dan 4 -dU, sehingga dapat disimpulkan tidak ada masalah autokorelasi.

\subsubsection{Dampak Faktor Sosial Ekonomi Terhadap \\ Luas Lahan Tanaman Pangan \\ Dampak perubahan faktor sosial dan ekonomi} terhadap luas lahan tanaman pangan terlihat dari hasil estimasi yang tertera pada Tabel 1 berikut:
Tabel 1. Hasil Estimasi Dampak Faktor Sosial Ekonomi Terhadap Luas Areal Tanaman Pangan

\begin{tabular}{|c|c|c|c|c|c|c|}
\hline \multirow[t]{2}{*}{$\begin{array}{c}\text { Variab } \\
\text { el }\end{array}$} & \multicolumn{2}{|c|}{$\begin{array}{c}\text { Porsi Luas } \\
\text { Areal Padi } \\
\text { Sawah } \\
\end{array}$} & \multicolumn{2}{|c|}{$\begin{array}{c}\text { Porsi Luas } \\
\text { Areal Padi } \\
\text { Ladang } \\
\end{array}$} & \multicolumn{2}{|c|}{$\begin{array}{c}\text { Porsi Luas } \\
\text { Areal } \\
\text { Jagung }\end{array}$} \\
\hline & $\begin{array}{l}\text { Koef } \\
\text { isien }\end{array}$ & $\begin{array}{l}\text { Pro } \\
b>t\end{array}$ & $\begin{array}{l}\text { Koef } \\
\text { isien }\end{array}$ & $\begin{array}{l}\text { Pro } \\
b>t\end{array}$ & $\begin{array}{l}\text { Koef } \\
\text { isien }\end{array}$ & $\begin{array}{l}\text { Pro } \\
b>t\end{array}$ \\
\hline Intercp & - & 0.0 & 96.84 & 0.0 & 73.59 & 0.0 \\
\hline Harga & 128.7 & 417 & 32 & 003 & 97 & 659 \\
\hline Kmdtasi & 60 & 0.0 & $5.19 \mathrm{E}$ & 0.2 & 6.64 & 0.6 \\
\hline S SS & 4.99 & 063 & -7 & 166 & E-7 & 365 \\
\hline Pangan & E-6 & 0.0 & 0.000 & 0.0 & - & 0.0 \\
\hline S S & 0.000 & 031 & 13 & 019 & 0.000 & 083 \\
\hline Pertani & 32 & 0.9 & - & 0.2 & 18 & 0.9 \\
\hline an & - & 952 & 0.000 & 593 & - & 009 \\
\hline GDP & 1.46 & 0.0 & 01 & 0.6 & 2.09 & 0.4 \\
\hline Prkpita & E-7 & 029 & - & 455 & E-6 & 478 \\
\hline Pertmb & - & 0.1 & 0.000 & 0.6 & - & 0.3 \\
\hline h Eko & 0.002 & 527 & 10 & 894 & 0.000 & 977 \\
\hline Prtmbh & 16 & 0.8 & - & $\mathbf{0 . 0}$ & 29 & 0.6 \\
\hline nPddk & - & 487 & $2.67 \mathrm{E}$ & 258 & - & 120 \\
\hline TK & 0.000 & 0.2 & -6 & 0.1 & 7.82 & 0.9 \\
\hline Prtisips & 02 & 875 & - & 719 & E-6 & 819 \\
\hline i Angkt & - & 0.4 & 0.000 & 0.4 & - & 0.5 \\
\hline Kerja & 0.000 & 597 & 16 & 047 & 0.000 & 354 \\
\hline Deped & 02 & 0.0 & 0.000 & 0.0 & 04 & 0.0 \\
\hline Ratio & 0.000 & 420 & 08 & 004 & 1.79 & 703 \\
\hline Tahun & 12 & 0 & - & 0 & E-6 & 0 \\
\hline $\mathrm{F}$ & - & 0 & 0.000 & 0 & - & 0 \\
\hline Value & 0.000 & 0 & 05 & 0 & 0.000 & 0 \\
\hline Prob > & 09 & & - & & 05 & \\
\hline $\mathrm{F}$ & - & & 0.048 & & - & \\
\hline R- & 0.064 & & 10 & & 0.036 & \\
\hline Square & 47 & & 65.38 & & 39 & \\
\hline & 14.32 & & 00 & & 3.840 & \\
\hline & 00 & & $<.000$ & & 00 & \\
\hline & 0.000 & & 10 & & 0.020 & \\
\hline & 10 & & 0.987 & & 50 & \\
\hline & 0.945 & & 41 & & 0.821 & \\
\hline & 01 & & & & 77 & \\
\hline
\end{tabular}
berpengaruh nyata pada tingkat kepercayaan $90 \%$ (P < $0.10)$

Berdasarkan tabel diatas terlihat bahwa variabel harga komoditas, share subsektor pangan kecuali pada porsi luas areal jagung, tingkat partisipasi angkatan kerja, memiliki tanda positif sedangkan share sektor pertanian, GDP perkapita, pertumbuhan ekonomi, pertumbuhan penduduk, dependency ratio, dan variabel tahun memiliki tanda negatif pada komoditas pangan (padi sawah, padi ladang, dan jagung). Kondisi ini sesuai dengan parameter dugaan (hipotesis penelitian) kecuali parameter share sektor pertanian dan parameter share subsektor pangan pada luas areal jagung.

Hasil estimasi menggunakan metode SUR terhadap luas areal padi sawah diperoleh nilai $\mathrm{R}$ - 
square 0.94501 menunjukkan bahwa sekitar 94,5 persen variasi luas lahan padi sawah dapat dijelaskan oleh variabel sosial dan ekonomi dalam penelitian. Variabel faktor sosial ekonomi secara bersama-sama berpengaruh signifikan terhadap luas lahan padi sawah pada level 0.0001. Secara parsial harga beras, share subsektor pangan, GDP perkapita dan variabel tahun berpengaruh signifikan terhadap luas lahan padi sawah. Harga beras berpengaruh nyata terhadap luas areal padi sawah dengan koefisien 0,0000499 diinterpretasikan sebagai rata-rata perubahan (peningkatan) pada porsi luas areal padi sawah sebesar 0,0000499 ketika harga meningkat satu persen, berpengaruh signifikan pada level 0,0063. Kondisi ini dapat dimengerti mengingat harga merupakan indikator bagi petani dalam berproduksi usahatani. Harga juga merupakan harapan penghasilan bagi petani. Disaat harga rendah maka petani cenderung beralih ke komoditas lain yang harganya lebih tinggi dan menggunakan lahannya untuk memproduksi komoditas tersebut dan begitu juga sebaliknya. Selain harga beras, variabel yang berpengaruh signifikan pada level 0,0031 terhadap luas areal padi sawah adalah share subsektor pangan dimana terjadi peningkatan porsi luas areal padi sawah rata-rata 0.00032 persen ketika Share Subsektor Pangan juga meningkat sebesar satu persen. Pengaruh share subsektor pangan berbanding lurus dengan porsi luas areal padi sawah dikarenakan padi merupakan bahan makanan pokok utama yang paling banyak diusahakan dan merupakan penyumbang utama yang berkontribusi besar terhadap tanaman pangan di Provinsi Jambi. GDP perkapita juga berpengaruh signifikan terhadap luas areal padi sawah pada level 0,0029 dengan koefisien negatif yang berarti terjadi penurunan porsi luas arel padi sawah sebesar 0,00216 ketika GDP perkapita naik satu persen, diduga peningkatan GDP perkapita tersebut diperoleh dari peralihan matapencaharian petani padi sawah ke sektor lain yang lebih tinggi pendapatannya. Hampir sama dengan penelitian lain yang menyatakan bahwa pengurangan luas lahan petani berdampak pada peningkatan pendapatan petani, hal ini dikarenakan adanya tambahan pendapatan dari sektor lain [5]. Berdasarkan perkembangan dari tahun ketahun terdapat kecenderung penurunan luas areal padi sawah setiap tahunnya, terbukti dari tingkat signifikan variabel tahun sebesar 0.0420 dengan koefisien -0.0644 yang dapat diinterpretasikan sebagai porsi luas areal padi sawah menurun rata-rata 0.0644 persen setiap tahunnya.

Hasil estimasi menggunakan metode SUR terhadap luas areal padi ladang diperoleh nilai Rsquare 0.98741 menunjukkan bahwa sekitar 98,741 persen variasi luas lahan padi ladang dapat dijelaskan oleh variabel sosial dan ekonomi dalam penelitian. Secara bersama-sama variabel faktor sosial ekonomi berpengaruh signifikan terhadap porsi luas areal padi ladang dengan nilai Prob > F pada level $<0.0001$. Secara parsial share subsektor pangan, pertumbuhan penduduk dan variabel tahun masing-masing berpengaruh signifikan terhadap porsi luas areal padi ladang yang terlihat dari nilai Prob> t. Share subsektor pangan berpengaruh signifikan terhadap porsi luas areal padi sawah pada level 0.0019 dengan koefisien 0.00013 yang dapat diinterpretasikan sebagai rata-rata peningkatan luas areal padi ladang ketika share subsektor pangan meningkat satu persen. Pengaruh yang positif ini dikarenakan padi memberikan kontribusi paling besar pada subsektor tanaman pangan, terbukti dari luasan lahan padi yang begitu besar dibanding luas lahan tanaman pangan yang lain. Pertumbuhan penduduk secara parsial berpengaruh signifikan terhadap porsi luas areal padi ladang pada level 0.0258 dengan koefisien -0.00016 yang dapat diinterpretasikan sebagai luas areal padi ladang menurun rata-rata 0.00016 ketika pertumbuhan penduduk meningkat satu persen. hal ini sejalan dengan penelitian lain [6] yang mengatakan bahwa pertumbuhan penduduk menyebabkan makin mengecilnya persediaan lahan rata-rata perorang.

Hasil estimasi menggunakan metode SUR terhadap porsi luas areal jagung diperoleh nilai Rsquare 0.82177 menunjukkan bahwa sekitar 82,177 persen variasi porsi luas areal jagung dapat dijelaskan oleh variabel sosial dan ekonomi dalam penelitian. Variabel faktor sosial ekonomi secara bersama-sama berpengaruh signifikan terhadap porsi luas areal jagung dengan nilai Prob > F pada level 0.02050. Secara parsial share subsektor pangan dan variabel tahun masing-masing berpengaruh signifikan terhadap porsi luas areal jagung yang terlihat dari nilai Prob $>t$. Share subsektor pangan berpengaruh signifikan terhadap porsi luas areal jagung pada level 0.0083 dengan koefisien -0.00018 yang dapat diartikan sebagai rata-rata penurunan luas lahan jagung ketika share subsektor pangan meningkat satu persen. Share subsektor pangan memiliki tanda berbeda yakni tanda negatif, berarti dimana share subsektor pangan yang meningkat justru mengurangi luas lahan jagung. Share subsektor pangan sebagian besar dikontribusi oleh komoditas padi, baik padi sawah maupun padi ladang yang merupakan bahan makan pokok masyarakat Provinsi Jambi. Padi ladang dan jagung sama-sama ditanam dilahan kering diduga terjadi kompetisi penggunaan lahan antara kedua komoditas tersebut apabila luas lahan jagung meningkat maka luas lahan padi ladang akan turun sehingga kontribusi padi ladang terhadap share subsektor pangan menurun. Selanjutnya akan berpengaruh terhadap kontribusinya yang besar pada subsektor tanaman pangan. Perkembangan luas lahan jagung dari tahun ke tahun ditunjukkan oleh hasil estimasi nilai prob $>\mathrm{t}$ variabel tahun, dengan koefisien -0.02243 yang berarti terjadi penurunan luas lahan jagung rata-rata 0.02243 persen setiap tahunnya. Akan tetapi tidak berpengaruh signifikan pada selang kepercayaan 90 persen. 


\subsubsection{Dampak Perubahan Faktor Sosial Ekonomi Terhadap Luas Lahan Tanaman Perkebunan}

Dampak perubahan faktor sosial ekonomi terhadap luas lahan tanaman perkebunan, dapat dilihat dari hasil estimasi pada Lampiran 1. Berdasarkan hasil estimasi terlihat bahwa variabel share sektor perkebunan, pertumbuhan ekonomi, tingkat partisipasi angkatan kerja bertanda positif, sedangkan variabel pertumbuhan penduduk, dependency ratio memiliki tanda negatif diseluruh luas lahan tanaman perkebunan. Variabel harga komoditas, share sektor pertanian, GDP perkapita, dan tahun bertanda positif hampir di seluruh luas lahan tanaman perkebunan. Kondisi ini sesuai dengan parameter dugaan (hipotesis penelitian).

Hasil estimasi menggunakan metode SUR terhadap luas areal karet diperoleh nilai $\mathrm{R}$-square sebesar 0.9929 yang berarti 99,29 persen variasi luas lahan karet dapat dijelaskan oleh variabel sosial ekonomi yang terdapat dalam model penelitian. Secara bersama-sama variabel faktor sosial ekonomi dalam penelitian ini berpengaruh signifikan pada level $<.0001$ terhadap luas lahan karet yang terlihat dari nilai prob> F. Secara parsial variabel harga karet, share sektor pertanian, GDP perkapita dan pertumbuhan ekonomi masing-masing berpengaruh signifikan terhadap luas lahan karet. Luas lahan karet dipengaruhi signifikan pada level 0.0002 oleh harga dengan pengaruh positif. Berdasarkan hasil estimasi luas lahan karet akan meningkat rata-rata 0.00003 persen ketika harga karet meningkat sebesar satu persen. Harga karet yang tinggi membuat petani tergiur akan keuntungan yang diperoleh sehingga mereka menggunakan lahan untuk menanam karet. Hal ini terbukti dari data yang diperoleh bahwa harga karet yang meningkat cukup besar di tahun 2005 membuat luas lahan karet juga meningkat 55.150 hektar [3]. Kenaikan harga karet alam Indonesia akan diikuti oleh peningkatan areal perkebunan karet baik oleh petani rakyat maupun perusahaan besar [7]. Hasil estimasi menunjukkan share sektor pertanian berpengaruh signifikan pada level 0.0001. Pengaruh yang positif antara luas lahan karet dengan share sektor pertanian dimana rata-rata perubahan luas lahan karet 0,00023 persen ketika share sektor pertanian meningkat sebesar satu persen. Kondisi ini dapat dipahami mengingat sebagian besar masyarakat Provinsi Jambi memiliki mata pencaharian disektor pertanian khususnya sebagai petani karet dan sawit. Pernyataan ini juga didukung oleh hasil penelitian lain (8) yang mengatakan bahwa kondisi sektor pertanian yang menjadi leading sektor dikarenakan sebagian besar masyarakat Provinsi Jambi memiliki mata pencaharian di sektor pertanian khususnya perkebunan karet dan sawit. Luas lahan karet secara signifikan dipengaruhi oleh GDP perkapita pada level 0.0003 dimana, luas lahan karet meningkat rata-rata 0.0042 ketika GDP perkapita meningkat sebesar satu persen. Hubungan yang positif antara GDP perkapita dengan luas lahan karet dikarenakan sebagian besar pendapatan masyarakat Provinsi Jambi diperoleh dari penghasilan dalam berkebun karet. Selain GDP perkapita, variabel pertumbuhan ekonomi juga berpengaruh signifikan pada level 0.0033 dan berpengaruh positif dengan luas lahan karet dimana rata-rata 0,00010 persen luas lahan karet meningkat ketika pertumbuhan ekonomi meningkat sebesar satu persen. Hal ini dapat dijelaskan oleh masih dominannya kontribusi sektor pertanian khususnya subsektor perkebunan karet yang masih dominan terhadap perekonomian Provinsi Jambi, sehingga meningkatnya luas lahan karet akan berdampak pada peningkatan pertumbuhan ekonomi di Provinsi Jambi. Jika dilihat dari perkembangan tahun ke tahun menunjukkan adanya perubahan positif luas areal karet yaitu meningkat sebesar 0.02717 persen pertahun akan tetapi perubahan tersebut tidak signifikan.

Hasil estimasi menggunakan metode SUR terhadap luas areal kelapa sawit diperoleh nilai Rsquare sebesar 0.9979 yang berarti 99,79 persen variasi luas lahan kelapa sawit dapat dijelaskan oleh variabel sosial ekonomi yang terdapat dalam model penelitian. Secara bersama-sama variabel faktor sosial ekonomi dalam penelitian ini berpengaruh signifikan pada level <.0001 terhadap luas lahan kelapa sawit yang terlihat dari nilai prob> F. Secara parsial variabel share subsektor perkebunan, dan variabel tahun masing-masing berpengaruh signifikan terhadap luas lahan kelapa sawit. Komoditas sawit merupakan salah satu komoditas unggulan Provinsi Jambi dengan laju pertumbuhan luas lahan tertinggi yaitu 5,87 persen pertahun. Kontribusi sawit yang besar terhadap PDRB sektor pertanian khususnya perkebunan, terbukti dari pengaruh yang positif antara luas lahan kelapa sawit dengan share subsektor perkebunan yang signifikan pada level 0.0581 dengan koefisien estimasi 0.00066 yang berarti terjadi peningkatan luas lahan sawit ratarata 0.00066 persen ketika share sektor perkebunan meningkat sebesar satu persen. Jika dilihat dari variabel tahun terdapat pengaruh yang signifikan terhadap luas lahan kelapa sawit pada level 0.0002 dengan koefisien 0,63691 yang dapat diartikan sebagai terjadi peningkatan luas lahan kelapa sawit rata-rata 0,63691 persen per tahun. Terdapat kecenderungan kompetisi antara kelapa sawit dengan karet alam atas sumberdaya lahan yang tersedia (7). Iklim ekonomi kelapa sawit yang mengarah pada peningkatan harga produk kelapa sawit dapat menstimulasi petani untuk mengkonversi lahan perkebunan karet menjadi lahan perkebunan kelapa sawit.

Hasil estimasi menggunakan metode SUR terhadap luas areal kelapa diperoleh nilai $\mathrm{R}$-square sebesar 0.8986 yang berarti 89,86 persen variasi luas lahan kelapa dapat dijelaskan oleh variabel sosial ekonomi yang terdapat dalam model penelitian. Secara bersama-sama variabel faktor sosial ekonomi dalam penelitian ini berpengaruh signifikan pada level 0.0017 terhadap luas lahan kelapa yang terlihat dari nilai prob> F. Secara parsial variabel share sektor 
pertanian, berpengaruh signifikan terhadap luas lahan kelapa pada level 0,0079. Kelapa memiliki kontribusi yang positif terhadap sektor pertanian terbukti dari nilai parameter estimasi yang bertanda positif, dimana rata-rata terjadi peningkatan luas lahan kelapa sebesar 0.00004 persen ketika share sektor pertanian meningkat sebesar satu persen. hal ini dapat dimengerti mengingat kelapa merupakan salah satu komoditas unggulan Provinsi Jambi. Akan tetapi jika dilihat dari perkembangannya tahun ke tahun terdapat penurunan luas lahan kelapa. Berdasarkan hasil estimasi terdapat trend penurunan luas lahan kelapa sebesar 0.00637 persen pertahun, akan tetapi tidak signifikan pada level 0,1 persen.

Hasil estimasi menggunakan metode SUR terhadap luas areal kopi diperoleh nilai $\mathrm{R}$-square sebesar 0.9710 yang berarti 97,10 persen variasi luas lahan kopi dapat dijelaskan oleh variabel sosial ekonomi yang terdapat dalam model penelitian. Secara bersama-sama variabel faktor sosial ekonomi dalam penelitian ini berpengaruh signifikan pada level $<.0001$ terhadap luas lahan kopi yang terlihat dari nilai prob> F. Secara parsial variabel share sektor pertanian, GDP perkapita, pertumbuhan ekonomi, pertumbuhan penduduk dan variabel tahun masing-masing berpengaruh signifikan terhadap luas lahan kopi. Hasil estimasi dampak faktor sosial ekonomi terhadap luas lahan kopi terlihat bahwa terdapat pengaruh yang signifikan variabel share sektor pertanian pada level 0.001 dengan koefisien 0.00002 yang dapat dinterpretasikan sebagai rata-rata perubahan luas lahan kopi (yaitu meningkat sebesar 0.00002 persen) ketika share sektor pertanian meningkat sebesar satu persen. Sama halnya dengan komoditas unggulan lainnya, komoditas kopi juga memberikan kontribusi yang positif terhadap PDRB sektor pertanian. Variabel GDP perkapita juga mempunyai pengaruh yang positif terhadap luas lahan kopi dan berpengaruh signifikan pada level 0.0002 dengan koefisien 0.00041 yang berarti bahwa terdapat peningkatan luas lahan kopi rata-rata sebesar 0.00041 persen ketika GDP perkapita meningkat satu persen. Keadaan ini mengindikasikan penghasilan yang diperoleh dari bertani kopi bisa menambah pendapatan perkapita penduduk. Pertumbuhan ekonomi juga berpengaruh signifikan terhadap luas lahan kopi pada level 0,0051 dengan koefisien 0,000074 yang dapat diinterpretasikan sebagai rata-rata terjadinya peningkatan luas lahan kopi ketika pertumbuhan ekonomi meningkat sebesar satu persen. Kondisi ini mencerminkan bahwa komoditas kopi masih memberikan kontribusi yang positif terhadap perekonomian Provinsi Jambi. Hal ini juga dapat dilihat dari share tenaga kerja pertanian yang berpengaruh signifikan pada level 0,033 dengan koefisien 0,00003 yang berarti terjadi peningkatan luas lahan kopi rata-rata 0,00003 persen ketika share tenaga kerja meningkat sebesar satu persen. Disisi lain terdapat pengaruh negatif pertumbuhan penduduk dengan luas lahan kopi dimana terjadi penurunan luas areal kopi rata-rata sebesar 0,00005 persen ketika pertumbuhan penduduk meningkat sebesar satu persen, signifikan pada level 0,0234. Hasil estimasi ini mengindikasikan bahwa terdapat lahan tanaman budidaya (kopi)yang digunakan penduduk sebagai sarana pemukiman, seperti yang diungkapkan oleh Lestari (2011) dalam penelitiannya yang mengatakan bahwa terjadi konversi lahan pertanian menjadi lahan pemukiman dan prasarana umum yang disebabkan oleh peningkatan jumlah penduduk. Dilihat dari pengaruh variabel tahun terhadap luas lahan kopi yang signifikan pada level 0,0030 terdapat kecenderungan peningkatan luas lahan kopi sebesar 0,02326 persen setiap tahunnya.

Hasil estimasi menggunakan metode SUR terhadap luas areal pinang diperoleh nilai R-square sebesar 0.9812 yang berarti 98,12 persen variasi luas lahan pinang dapat dijelaskan oleh variabel sosial ekonomi yang terdapat dalam model penelitian. Secara bersama-sama variabel faktor sosial ekonomi dalam penelitian ini berpengaruh signifikan pada level $<.0001$ terhadap luas lahan pinang yang terlihat dari nilai prob> F. Secara parsial variabel share subsektor perkebunan, share sektor pertanian dan variabel tahun masing-masing berpengaruh signifikan terhadap luas lahan pinang. Hasil estimasi menunjukkan terdapat juga pengaruh yang signifikan antara share subsektor perkebunan dan share sektor pertanian terhadap luas lahan pinang, masing-masing pada level 0.058 dan 0.011. Terdapat rata-rata peningkatan luas lahan pinang sebesar 0.00010 ketika share subsektor perkebunan meningkat satu persen dan terjadi peningkatan luas lahan pinang sebesar 0.00002 ketika share sektor pertanian meningkat satu persen. Pengaruh yang positif ini disebabkan oleh terdapatnya kontribusi pinang yang relatif tinggi terhadap subsektor perkebunan yang selanjutnya berdampak pada kontribusi sektor pertanian terhadap PDRB Provinsi Jambi. Dilihat dari perkembangannya tahun ke tahun terdapat pengaruh yang signifikan antara variabel tahun dengan luas lahan pinang pada level 0.012 dengan kecenderungan terjadi peningkatan luas lahan pinang sebesar 0.05054 pertahun.

\subsection{Pola Konversi Lahan Tanaman Budidaya}

Pola konversi lahan antar berbagai komoditas tanaman budidaya di Provinsi Jambi dapat diproksi melalui porsi luas areal budidaya masing-masing komoditas. Konversi lahan antar berbagai komoditas tanaman budidaya berlangsung dinamis dan dipengaruhi oleh berbagai faktor sosial dan ekonomi. Hasil estimasi menunjukkan terdapat peningkatan luas lahan beberapa tanaman perkebunan dan hortikultura seperti kelapa sawit, kopi, pinang, karet, pisang dan kentang. Sedangkan luas lahan tanaman pangan (padi sawah, padi ladang, jagung) serta komoditas tanaman perkebunan lain seperti kelapa dan kulit manis mengalami penurunan luas lahan.

Berdasarkan model korelasi silang (cross model correlation) hasil estimasi model persamaan SUR (Lampiran 2) dan trend perkembangan luas areal 
komoditas tanaman yang positif (mengalami peningkatan dari tahun ke tahun), maka secara ringkas pola konversi lahan disajikan pada Gambar 1.

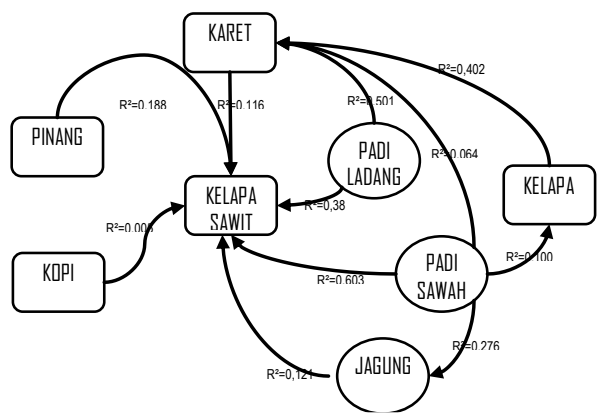

Gambar 1. Pola Konversi Lahan

Tanaman Budidaya

Gambar 1 mampu menunjukkan fenomena perubahan pola penggunaan lahan budidaya di Provinsi Jambi dengan 2 (dua) isu penting yaitu terjadinya konversi lahan tanaman pangan menjadi lahan tanaman perkebunan sehingga semakin menipisnya ketersediaan lahan tanaman pangan terutama padi (padi sawah dan padi ladang), ekspansi perkebunan sawit dan karet.

Ekspansi perkebunan kelapa sawit berasal dari konversi lahan budidaya lainnya kecuali kelapa. Kelapa merupakan tanaman sepesifik wilayah pesisir pantai timur Provinsi Jambi sehingga konversi menjadi perkebunan kelapa sawit masih belum banyak terjadi. Perkembangan luas areal perkebunan kelapa sawit dapat berasal dari konversi lahan perkebunan karet, pinang, dan kopi serta konversi lahan tanaman pangan baik lahan kering maupun lahan basah (padi sawah). Setiap hektar kenaikan luas areal perkebunan kelapa sawit bersama-sama dengan kenaikan 0,1667 Ha kelapa dan 0,3536 Ha jagung akan diikuti dengan penurunan 0,6039 Ha padi sawah, 0,0386 Ha padi ladang, 0,1165 Ha perkebunan karet, 0,0050 Ha perkebunan kopi, 0,1886 Ha perkebunan pinang, 0,13316 Ha.

Ekspansi perkebunan karet di Provinsi Jambi akhir-akhir ini mulai menunjukkan perlambatan dengan perkembangan yang cenderung mendatar (leveling off), meskipun begitu luas lahan perkebunan karet masih menempati posisi pertama terluas. Lahan perkebunan karet hampir merata pada seluruh kabupaten di Provinsi Jambi. Terdapat kompetisi antara perkebunan karet dan kelapa sawit atas sumberdaya lahan dimana terjadi konversi lahan perkebunan karet menjadi lahan perkebunan kelapa sawit yang disebabkan oleh harga karet yang kurang baik dan adanya keterbatasan cadangan lahan pertanian yang tersedia untuk perkebunan karet. Hal sama juga dikemukan dalam penelitian lain yang mengatakan bahwa terdapat sejumlah lahan perkebunan karet yang dikonversi menjadi lahan perkebunan kelapa sawit sebagai akibat dari masuknya teknologi kelapa sawit ke beberapa daerah sentra produksi karet melalui program transmigrasi. Tidak hanya perkebunan karet rakyat, perkebunan besar juga telah merelokasi sejumlah lahan perkebunan karet mereka menjadi lahan perkebunan kelapa sawit disebabkan harga karet alam dunia yang memiliki trend pertumbuhan negatif (7). Perkembangan luas areal perkebunan karet dapat berasal dari konversi lahan perkebunan kulit manis pada wilayah dataran tinggi dan kelapa pada wilayah dataran rendah. Setiap hektar kenaikan luas areal perkebunan karet bersamasama dengan kenaikan 0,3245 Ha kopi akan diikuti oleh penurunan luas tanaman pangan seperti penurunan padi sawah sebesar 0,0649 $\mathrm{Ha}$, padi ladang $0,5012 \mathrm{Ha}$, dan jagung $0,1606 \mathrm{Ha}$, penurunan luas areal perkebunan kelapa sebesar 0,4027 Ha.

Konversi lahan tanaman pangan terutama padi menjadi lahan tanaman perkebunan akibat dari adanya ekspansi lahan perkebunan menyebabkan semakin menipisnya luas areal tanaman pangan (padi sawah dan padi ladang). Hal ini terlihat dari trend penurunan luas lahan tanaman pangan. Konversi lahan pangan yang terus terjadi akan mengancam ketahanan pangan di Provinsi Jambi. Permasalahan ketahanan pangan ini tidak hanya menurunkan jumlah produksi beras tetapi juga akan mengganggu stabilitas perkembangan penduduk, ekonomi, sosial, dan politik. Jumlah lahan tanaman padi sebagai bahan makan pokok yang terus menurun akan menurunkan produksi beras yang dihasilkan. Hal ini sangat berbanding terbalik dengan adanya jumlah penduduk yang setiap tahun terus meningkat. Jika kondisi ini terus berlangsung diperkirakan ketersediaan produksi beras akan lebih kecil dari kebutuhan beras sehingga akan terjadi kekurangan beras. Setiap hektar penurunan luas areal padi sawah diperkirakan $0,6038 \mathrm{Ha}$ atau $60,38 \%$ dikonversi menjadi areal perkebunan kelapa sawit, $0,0649 \mathrm{Ha}$ atau 6,49 \% dikonversi menjadi areal perkebunan karet, 0,1004 Ha kelapa dan 0,2769 Ha jagung. Selain padi sawah luas areal padi ladang juga mengalami penurunan. Setiap hektar penurunan padi ladang diperkirakan sebesar 0,5012 Ha dikonversi menjadi perkebunan karet dan 0,3857 Ha dikonversi menjadi perkebunan kelapa sawit.

\section{Kesimpulan}

Berdasarkan hasil analisis dan pembahasan maka dapat diambil beberapa simpulan sebagai berikut:

1. Perubahan yang terjadi pada luas areal tanaman pangan lebih banyak dipengaruhi oleh faktor ekonomi (harga komoditas, share subsektor pangan) dan pertumbuhan penduduk dengan kecenderungan menurun setiap tahunnya.

2. Perubahan yang terjadi pada luas areal tanaman perkebunan lebih banyak dipengaruhi oleh struktur ekonomi (harga komoditas, share sektor pertanian, share subsektor perkebunan, GDP perkapita, pertumbuhan ekonomi) dan faktor sosial (tenaga kerja dan pertumbuhan penduduk) dengan kecenderungan meningkat setiap tahunnya kecuali kelapa. 
3. Pola konversi lahan tanaman budidaya di Provinsi Jambi yaitu perubahan pola penggunaan lahan budidaya dari lahan tanaman pangan menjadi lahan tanaman perkebunan dan ekspansi perkebunan sawit.

\section{Daftar Pustaka}

1. Lestari, Astri. Dampak Sosio-Ekonomis dan SosioEkologis Konversi Lahan Pertanian. Bogor: Skripsi. Institut Pertanian Bogor, 2011.

2. Pemerintah Provinsi Jambi. [Online] [Cited: Maret 17, 2016.] http://jambiprov.go.id.

3. Statistik, Badan Pusat. Jambi dalam angka tahun. Jambi : BPS, 2015.

4. Sitepu, Rasidin Karo-karo dan Sinaga, Bonar M. Aplikasi Model Ekonometrika Estimasi Simulasi dan Peramalan Menggunakan Program SAS. . Bogor: Program Studi Ilmu Ekonomi Pertanian Sekolah Pascasarjana Institut Pertanian Bogor, 2006.

5. Aprilia, Luki. Dampak Alih Fungsi Lahan Pertanian Terhadap Kondisi Sosial Ekonomi Petani Perkotaan di Kecamatan Depok, Kabupaten Sleman, D.I. Yogyakarta. Yogyakarta: Skripsi. Universitas Gadjah Mada, 2012.

6. Astuti, Umi Pudji, Wibowo, Wahyu and Ishak, Andi. Fakto-Faktor Yang Mempengaruhi Alih Fungsi Lahan Pangan Menjadi Kelapa Sawit di Bengkulu: Kasus Petani di Desa Kungkai Baru. Bengkulu : Balai Pengkajian Pertanian Bengkulu, 2011.

7. Napitupulu, Dompak. Simulasi Kebijakan Menghadapi Kesepakatan Tripatite dan perdagangan Bebas Model Perdagangan Karet Alam Indonesia. Malang: Disertasi. Program Pascasarja Universitas Brawijaya, 2004.

8. Pola dan Intensitas Konversi Lahan Pertanian di Kota Semarang Tahun 2000-2009. Hariyanto. 1, Semarang : Jurnal Geografi, 2010, Vol. 7. 


\begin{tabular}{|c|c|c|c|c|c|c|c|c|c|c|c|}
\hline \multirow[t]{2}{*}{ No. } & \multirow[t]{2}{*}{ Variabel } & \multicolumn{2}{|c|}{ Karet } & \multicolumn{2}{|c|}{ Kelapa Sawit } & \multicolumn{2}{|c|}{ Kelapa } & \multicolumn{2}{|c|}{ Kopi } & \multicolumn{2}{|c|}{ Pinang } \\
\hline & & Koefisien & Prob & Koefisien & Prob & Koefisien & Prob & Koefisien & Prob & Koefisien & Prob \\
\hline 1. & Intercept & -40.2397 & 0.7455 & -1255.20 & 0.0002 & 14.7119 & 0.7758 & -45.145 & 0.0032 & -99.9576 & 0.0112 \\
\hline 2. & Harga Komoditas & 2.99E-6 & 0.0020 & $2.32 \mathrm{E}-6$ & 0.3694 & $4.72 \mathrm{E}-7$ & 0.4813 & $5.99 \mathrm{E}-7$ & 0.2777 & $9.72 \mathrm{E}-8$ & 0.5771 \\
\hline 3. & Share SS Perkebunan & $8.53 \mathrm{E}-8$ & 0.9996 & 0.00066 & 0.0581 & 0.00005 & 0.5593 & 0.00003 & 0.1509 & 0.00010 & 0.0580 \\
\hline 4. & Share Sektor Pertanian & 0.00023 & $<.0001$ & 0.00005 & 0.4465 & 0.00004 & 0.0079 & 0.00002 & $<.0001$ & 0.00002 & 0.0111 \\
\hline 5. & GDP perkapita & 0.00420 & 0.0003 & 0.00019 & 0.8963 & 0.00043 & 0.1619 & 0.00041 & 0.0002 & 0.00005 & 0.7858 \\
\hline 6. & Pertumbuhan Ekonomi & 0.00010 & 0.0033 & 0.00001 & 0.7931 & $9.55 \mathrm{E}-6$ & 0.3136 & $7.42 \mathrm{E}-6$ & 0.0051 & $5.54 \mathrm{E}-6$ & 0.3796 \\
\hline 7. & Pertumbuhan Penduduk & -0.00011 & 0.6224 & -0.00055 & 0.1626 & -0.00007 & 0.3703 & -0.00005 & 0.0234 & -0.00003 & 0.4501 \\
\hline 8. & TK Prtisipsi Angkt Kerja & 0.00005 & 0.8261 & 0.00032 & 0.3900 & 0.00005 & 0.4777 & 0.00002 & 0.2621 & -0.01358 & 0.0937 \\
\hline 9. & Depedency Ratio & $-5.32 \mathrm{E}-6$ & 0.9820 & -0.00047 & 0.2325 & -0.00006 & 0.4391 & -0.00001 & 0.4936 & -0.00002 & 0.6432 \\
\hline 10. & Tahun & 0.02717 & 0.6691 & 0.63691 & 0.0002 & -0.00637 & 0.8095 & 0.02326 & 0.0030 & 0.05054 & 0.0120 \\
\hline 11. & F Value & 116.470 & 0 & 399.140 & 0 & 7.38000 & 0 & 27.9100 & 0 & 43.6200 & 0 \\
\hline 12. & Prob $>\mathrm{F}$ & $<.00010$ & 0 & $<.00010$ & 0 & 0.00170 & 0 & $<.00010$ & 0 & $<.00010$ & 0 \\
\hline 13. & R-Square & 0.99290 & 0 & 0.99792 & 0 & 0.89860 & 0 & 0.97101 & 0 & 0.98125 & 0 \\
\hline
\end{tabular}

Lampiran 1. Hasil Estimasi Dampak Faktor Sosial Ekonomi Terhadap Luas Areal Tanaman Perkebunan

Lampiran 1. Hasil Estimasi Dampak Faktor Sosial Ekonomi Terhadap Luas Areal Tanaman Perkebunan

Lampiran 2. Hasil Estimasi Hubungan Luas Lahan Antara Berbagai Komoditas Tanaman Budidaya

\begin{tabular}{lrrrrrrrr}
\hline VARIABEL & \multicolumn{1}{c}{ PLAPS } & \multicolumn{1}{c}{ PLAPD } & \multicolumn{1}{c}{ PLAJG } & \multicolumn{1}{c}{ PLAKR } & \multicolumn{1}{c}{ PLAKS } & \multicolumn{1}{c}{ PLAKL } & \multicolumn{1}{l}{ PLAKP } & \multicolumn{1}{c}{ PLAPN } \\
\hline PLAPS & $\mathbf{1 . 0 0 0 0 0}$ & 0.35894 & -0.27698 & -0.06499 & -0.60387 & -0.10047 & -0.03071 & 0.06330 \\
PLAPD & 0.35894 & $\mathbf{1 . 0 0 0 0 0}$ & 0.22146 & -0.50125 & -0.38578 & 0.29347 & 0.17058 & 0.45668 \\
PLAJG & -0.27698 & 0.22146 & $\mathbf{1 . 0 0 0 0 0}$ & -0.16069 & 0.35358 & 0.46178 & 0.53996 & 0.28619 \\
PLAKR & -0.06499 & -0.50125 & -0.16069 & $\mathbf{1 . 0 0 0 0 0}$ & -0.11654 & -0.40275 & 0.32451 & -0.01582 \\
PLAKS & -0.60387 & -0.38578 & 0.35358 & -0.11654 & $\mathbf{1 . 0 0 0 0 0}$ & 0.16675 & -0.00540 & -0.18863 \\
PLAKL & -0.10047 & 0.29347 & 0.46178 & -0.40275 & 0.16675 & $\mathbf{1 . 0 0 0 0 0}$ & 0.10151 & 0.12474 \\
PLAKP & -0.03071 & 0.17058 & 0.53996 & 0.32451 & -0.00540 & 0.10151 & $\mathbf{1 . 0 0 0 0 0}$ & 0.37890 \\
PLAPN & 0.06330 & 0.45668 & 0.28619 & -0.01582 & -0.18863 & 0.12474 & 0.37890 & $\mathbf{1 . 0 0 0 0 0}$ \\
\hline
\end{tabular}

